\title{
Oswaldo Estrada. Ser mujer y estar presente: Disidencias de género en la literatura mexicana
}

contemporánea. México: UNAM, 2014.

La reflexión en torno a la construcción de la identidad femenina es la cuestión principal que vertebra toda la obra de Oswaldo Estrada. La paráfrasis a Sor Juana Inés de la Cruz en su título deriva en una doble vertiente de significado; por un lado, el análisis de la aparición de la mujer dentro de la narrativa mexicana contemporánea; por otro, la relevancia de esas autoras dentro del panorama literario nacional. Este anhelo por comprender la identidad mexicana así como la construcción femenina a través de su sociedad nos conduce al descubrimiento de nueve autoras cuya producción literaria es puesta en relación para establecer un diálogo intertextual en torno a dichos temas.

Siguiendo la estela de otros ensayos sobre narradoras mexicanas contemporáneas, Oswaldo Estrada las aúna y ofrece un análisis de su producción relacionándolas con las teorías de importantes autoras feministas como Simone de Beauvoir, Nelly Richard y Judith Butler. Esta decisión metodológica pone de manifiesto el auge de los estudios de género en la actualidad, su importancia a causa de la interdisciplinariedad de su enfoque y la invitación a una relectura de la tradición heredada y consagrada para abrir nuevas sendas que transitar y explorar.

La perspectiva desde la que el autor aborda las obras de estas escritoras las enmarca fuera de los cánones literarios establecidos y las vincula entre ellas mediante: «su facultad de articular un mensaje crítico con respecto a su mundo, la voluntad de crear espacios subversivos, contradictorios, incómodos» (13). Partiendo de la desigualdad existente entre géneros, la escritura se convierte en el espacio de reafirmación subjetiva y la construcción de la identidad femenina se rebela contra la figuración del patriarcado y otorga agencia a mujeres que son capaces de autorrepresentarse.

La oportuna propuesta de Estrada presenta un firme propósito que se basa en una nueva forma de interpretación y de prestigiar la literatura mexicana escrita por mujeres así como estimular a los lectores para que estos exploren nuevas vías de investigación en torno a estas autoras, que pese a las contribuciones aportadas hasta la fecha aún se ven en la necesidad de redescubrirse y ponderar la vigencia de sus ideas.

Estas voces descritas como «rebeldes» (12) conforman un panorama literario femenino en torno a la literatura mexicana de los siglos Xx y xxI que permite dar cuenta del rol y la actividad de la mujer intelectual y, como apunta Estrada, su capacidad para: "cuestionar estados de marginación y colonialidad, el devenir de la historia, divisiones de género o discursos que promueven la exclusión y la normalidad» (12). A lo largo de sus páginas el lector ha de valorar la precisión crítica y las reflexiones del autor que conducen a una lectura entre líneas de cada una de las narradoras, relacionando su escritura con otros elementos como la voz, el cuerpo, la identidad o la marginalidad.

Las voces femeninas que recoge esta obra se agrupan en tres bloques temáticos a partir de los cuales se articula la obra: el silencio; las historias, cartas y cuerpos; y las disidencias de identidad. En la primera parte se tratan tres autoras (Nellie Campobello, Rosario Castellanos y Elena Poniatowska), relacionadas por una referencia al silencio en el epígrafe que el lector puede interpretar en diferentes niveles: el silencio de la literatura mexicana escrita por mujeres dentro del mercado editorial; el silencio de las escritoras mexicanas en referencia a su identidad y su devenir en el ámbito laboral; y el silenciamiento de las mujeres dentro de las obras literarias.

Este último nivel está representado en la primera de las escritoras. Campobello destaca por retratar a las mujeres de un modo secundario aunque destacando la excentricidad de algunas de ellas como su madre y Nacha Ceniceros. Son modelos femeninos pasivos ante la figura masculina, que se describen de modo fragmentario para enfatizar así el lugar de 
marginalidad que ocupan. Convenientemente el autor remarca la posibilidad de un deseo implícito de trascender la condición femenina. La oscilación de algunos personajes femeninos entre la transgresión de su silencio y la sumisión a este como modo de aceptación o transgresión está presente en obras como Las manos de mamá (1937). Se modifica la identidad establecida hegemónicamente, convirtiendo así al personaje en cuestión como «artesana de una identidad autónoma» (53).

«Historias, cartas y cuerpos» emplea tres términos que se vinculan, en cada apartado, con la construcción identitaria de la mujer. El autor logra conectar las propuestas de las autoras (Carmen Boullosa, Monica Lavín y Margo Glantz), partiendo desde diferentes márgenes literarios. Margo Glantz es la pieza clave del cierre de este segundo bloque. Oswaldo Estrada hace una magnífica introducción de la producción de la autora como crítica literaria, investigadora y escritora, centrándose en la relación existente entre el cuerpo y la escritura de su última faceta. La lectura que el autor proporciona sobre la visión del cuerpo en Glantz se describe como cuidadosa y fragmentaria (170). Según el autor, este cuerpo sirve para construir una identidad disidente al discurso dominante y debatir otros aspectos como el erotismo o las divisiones de género dentro de las obras, enfrentando los límites de la marginalidad dentro de la escritura. Otro aspecto que Estrada apunta y que es crucial para la comprensión del imaginario de la escritora es la pretensión desmitificadora de la mujer en su obra, así como la conexión con otras escritoras como Castellanos. Su método para lograrlo consiste en problematizar «imágenes preconcebidas de género, amor, cuerpo" y tratar de encontrar una voz y un cuerpo propios (182).

La identidad aparece asociada en las tres últimas autoras (Rosa Beltrán, Rivera Garza y Guadalupe Nettel) con la otredad y la subalternidad para abordar sus disidencias, que, en múltiples ocasiones, se ven relegadas a zonas periféricas. La ambigua y compleja obra de Rivera Garza coincide con Rosa Beltrán en el uso de la locura, pero Estrada esclarece el modo de utilización de esa locura en Rivera Garza.
Se menciona que existe una «locura moral» (241). Esta es la que permite un espacio de otredad en el que la mujer puede redefinirse. Otro vínculo que permite conectar esta autora con otras escritoras de este ensayo es la relación entre cuerpo y escritura, elemento fundamental en la literatura de Glantz. En el caso de Rivera Garza, la violencia en el cuerpo de las mujeres se convierte en una de sus formas de representación. Así, en La muerte me da (2007) aparecen cuerpos mutilados y se relaciona con la actualidad social de los feminicidios en México.

Oportunamente, el autor caracteriza a Rivera Garza como una escritora transgresora, aspecto que ya se percibía en otras autoras como Carmen Boullosa, Mónica Lavín o Rosa Beltrán. Por consiguiente, sus personajes son caracterizados por Oswaldo Estrada con este calificativo. Desde Matilda, una prostituta transgresora en su obra Nadie me verá llorar (1999), y toda una ristra de personajes que establecen identidades alternativas a la heteronormatividad y reconstruyen su identidad «fuera de la sistematización de género", como en Lo anterior (2004) y en La cresta de Ilión (2001) (236), hasta la existencia de espacios marginales en que las mujeres se redefinen como la taiga en El mal de la taiga (2012). Las lecturas queer, que se realizan sobre alguna de sus obras, ofrecen al lector una nueva perspectiva de reflexión en torno al género y el hecho de señalarlas en este ensayo es un total acierto para explorar nuevas vías de investigación.

Aunque el ensayo se centre principalmente en la construcción identitaria y los temas relevantes que se vinculan a esa identidad, también se incluyen reflexiones acerca de la sociedad mexicana y sus problemáticas actuales. Con todo, escuchar este coro de voces femeninas guiadas e interpretadas por Oswaldo Estrada suscita en el lector una revisión de la literatura mexicana contemporánea explorando nuevos enfoques que contribuyen a mejorar la comprensión acerca de la coyuntura socio-cultural mexicana actual.

Soledad Castaño Santos Universidad de Valencia 